\title{
Infiltrative Tumor Margin
}

National Cancer Institute

\section{Source}

National Cancer Institute. Infiltrative Tumor Margin. NCI Thesaurus. Code C137710.

Describes a tumor border that is invading the adjacent tissue. 